\title{
Restorative Justice as an Effort to Solve Problems with Cooperative Crimes Acts
}

\author{
Dewi Nadya Maharani ${ }^{1}$, Faisal Santiago ${ }^{2}$ \\ \{Dewinadyamaharani@gmail.com ${ }^{1}$, faisalsantiago@gmail.com² ${ }^{2}$, \\ Universitas Borobudur, Jakarta, 13620, Jakarta, Indonesia ${ }^{1,2}$
}

\begin{abstract}
This paper analyzes the rules regarding criminal acts committed by cooperatives in Indonesia. Normative legal methods are used in this paper. The result is that Law No. 25 of 1992 on Cooperatives is not regulated regarding criminal sanctions. Even though the criminal acts committed by cooperatives are pretty often, and make unsettles the community. However, criminal sanctions for criminal acts committed by these cooperatives are regulated in other rules, such as the criminal code and the law regarding banking. Cooperatives are based on the principle of the family for the resolution of this criminal acts problems, based on this principle, one of which is using restorative justice. Therefore, criminal sanctions in tackling cooperative criminal acts are essential and can also be included with ballast. Nevertheless, it should not forget the family principle on which cooperatives are based, and we can be prioritizing restorative justice.
\end{abstract}

Keywords: Restorative Justice; Crimes Acts; Cooperatives

\section{Introduction}

Indonesia is quite known for its gotong-royong attitude, deliberation, and also the populist economy. One of the manifestations is the construction of the economy through cooperatives. A Cooperative is a business element comprising of an individual or agreeable legitimate substance dependent on the rule of Cooperatives and a group's financial development dependent on family standards. Cooperatives depend on Pancasila and the 1945 constitution and in light of family standards. Helpful expects to propel the government assistance of individuals specifically and society overall and partake in building the National monetary request to understand a high level, reasonable, and society dependent on Pancasila and the 1945 Constitution.

Today, about cooperatives managed in the Republic of Indonesia Law No. 25 of 1992 on Cooperatives. In any case, kindly note that connected cooperatives have been changed into the Law of the Republic of Indonesia Number 17 of 2012 concerning Cooperatives. Since changes to the standards with respect to cooperatives hurt the idea of cooperatives themselves, this new law was pronounced invalid by the Constitutional Court Decision No. 28/PUU-XI/2013. Thusly the situation of Law No. 25 of 1992 on Cooperatives was briefly reestablished until there was a law in regards to new cooperatives. 
In its implementation with the existence of this cooperative does also not cause a problem. However, there are several problems, such as the management of funds, the dishonesty of a cooperative manager, and other problems. Precisely this is often a stumbling block to enter into the realm of a criminal act. In addition to prison, there must be other concepts that fit the cooperative itself. For example, cooperatives adhere to the principle of the family. This is at least in harmony with the concept of restorative justice. It is hoped that restorative justice can be one of the priorities in solving some problems regarding cooperative criminal acts.

\section{Results and Discussion}

Cooperatives in their establishment are based on the Constitution 1945, precisely in Article 33 section (1), which peruses, "The economy is organized as a joint exertion dependent on family." This is additionally built up by Article 2 of Law No. 25 of 1992 on Cooperatives jo Law No. 11 of 2020 on Work Copyright (Cooperative Law) which peruses, "Cooperatives dependent on Pancasila and the 1945 constitution and in view of family standards". This is, obviously, maintainable with the standard of Cooperatives. In this way, cooperatives need to assume a basic part in setting up the economy dependent on family and monetary popular government, focusing on the local area's thriving, not simply individuals. As expressed in Article 3 of the Operating Law, "Cooperatives plan to propel the government assistance of individuals specifically and society overall and partake in building the National financial request to understand a high level, reasonable, and prosperous society dependent on Pancasila and the 1945 Constitution".

In the case of criminal sanctions, the Cooperative Law does not regulate it. However, not a few incidents of criminal acts committed by cooperatives, incredibly cooperative deserters. Primarily if it has been shaped as a savings and loan cooperative, ranging from the theft of cooperative funds, embezzlement of cooperative funds, management of funds outside the cooperative members without permission from the authorities, etc. As for alternative settlements regarding criminal acts committed by cooperatives can be subject to articles, such as:

a) In the Criminal Code

1. Article 372 of the Criminal Code

"Whoever purposefully and unlawfully had something that is entirely or somewhat has a place with someone else, however which is in his power not for the wrongdoing of being undermined with theft, with a most extreme detainment of four years or a greatest fine of 900 rupiahs."

2. Article 374 of the Criminal Code

"Embezzlement committed by a person whose embezzlement of goods is due to a working relationship or by search or because of a reward for it is punishable by imprisonment of a maximum of five years."

3. Article 378 of the Criminal Code

"Whoever to help himself or others unlawfully, by utilizing a bogus name, by duplicity, or a progression of falsehoods, move others to give up something to him, or to give obligations or wipe out receivables is compromised with misrepresentation with a most extreme jail term of four years."

b) Regulations outside the Criminal Code:

Article 46 of Law No. 7 of 1992 on Banking jo Law No. 10 of 1998 on Amendments to Law No. 7 of 1992 on Banking jo Law No. 11 of 2020 on Copyright Work (Banking Law): 
1. Anyone who gathers assets from the local area as stores as current records, term stores, authentications of store, investment funds, and additionally different structures that are compared with it without a permit to operate from the Minister as alluded to in Article 16 and Article 17, is threatened with imprisonment of a maximum of 15 (fifteen) years and a maximum fine of Rp. 10,000,000,000,- (ten billion rupiah).

2. Suppose the exercises alluded to in passage (1) will be done by a legitimate element as a restricted obligation organization. All things considered, association, establishment, or helpful, the indictment of the bodies being referred to will be completed either against the people who provide the request to carry out the thing or who go about as the innovator in the demonstration or against both.

In addition to the above rules, there may be many other rules related to criminal acts committed by cooperatives. However, the rules related to criminal acts with cooperatives themselves are not contained in the Cooperative Law or its derivative rules. Essentially, a criminal act can occur and be committed by anyone, including deserters and cooperative members. Although criminal sanctions are not regulated in the Cooperative Act directly, criminal sanctions that intersect with cooperatives are in other legal rules. Nevertheless, it should be noted that cooperatives are places where people help each other fulfill daily life in line with the family principles mentioned in the Cooperative Law. This family principle can also be applied in terms of resolving criminal acts committed by cooperatives. Because some of the considerations regarding the prison sentence are, it as such: [1] (a) Dehumanization of criminals; (b) Prisonization of inmates; (c) A place of contamination; (d) Short-term criminals; (e) Stigmatization.

Prison sentences imposed indirectly can be said to hurt the principle of the family itself. Therefore, the right concept is to focus on remedial equity. Remedial equity is the goal of criminal cases including culprits, casualties, casualties' families, and other related gatherings to together look for a reasonable arrangement by underlining recuperation back to its unique state and not reprisal (Law of the Republic of Indonesia Number 11 of 2012 concerning the Criminal Justice System of Children, Article 1 number 6). Muladi reveals in detail the following restorative justice characteristics [2]:

a. Crime is figured as an individual's offense against others and is viewed as a contention.

b. Focus consideration on addressing issues of responsibility and risk for what's to come.

c. Normative nature is based on exchange and arrangement.

d. Restitution as a method for the gatherings, compromise, and reclamation is the principle objective.

e. Justice is figured as a connection between privileges, passed judgment on dependent on outcomes.

f. Focus on consideration is centered around fixing social injuries because of wrongdoing.

g. Society is a facilitator in the remedial cycle.

$\mathrm{h}$. The job of casualties and culprits is perceived, both in the assurance of issues and the goal of the privileges and needs of casualties. Be that as it may, they should be urged to assume liability.

i. The culprit's responsibility is formed because of understanding his activities and choosing the best.

j. Criminal acts are perceived in a specific moral, social, and financial setting.

k. Stigma can be taken out through remedial

However, if we look at the Annex of the Decree of the Director-General of the General Judicial Agency Number: 1691 / DJU / SK / PS.00 / 12/2020 on guidelines for the application of restorative justice in the general court, in the scope of it is said, "this guideline is used in 
settlement of cases through remedial equity in minor violations, ladies' cases confronting the law, youngster cases, and opiates cases." So there are still constraints in the execution of this restorative justice. Though this could be an option to some cooperative cases regarding restorative justice, prison is not always the first choice. Cooperatives are based on family when there are problems that must also be pursued in a familial way.

If something like this happens and goes into the realm of law, restorative justice can be applied. For example, when the process takes place, it turns out that there is deliberation between the victim and the perpetrator and related elements to agree on certain things. If the perpetrator is fulfilled and carried out, the criminal process does not need to continue. As with the issue of state governance decisions, and administrative effort must certainly take precedence before entering the realm of trial.

However, it is also essential to know that this restorative justice must also be considered from all aspects. For example, from the amount of embezzled cooperative funds, the reasons for the perpetrators, deliberation agreements, etc. Many conditions must first be met to take the path with this restorative justice. For example, if the perpetrator does not have good intentions to carry out what he has agreed upon, criminal proceedings can be an option to keep going. This restorative justice is solving the problem of criminal behavior by re-leveling harmonization between the community, victims, and perpetrators.

\section{Acknowledgments}

The author would like to thank all those who helped and contributed to the writing of this article. Hopefully, this paper can help theoretically and practically for knowledge, especially in the field of law.

\section{References}

[1] Muladi dan Barda Nawawi Arief : Teori-Teori Dan Kebijakan Pidana. Alumni. Bandung, (1984)

[2] Muladi : Kapita Selekta Sistem Peradilan Pidana. B. P. Universitas Diponegoro. Semarang, (1995) 